\title{
CONTRIBUTIONS OF THE CHAPLAINCY SERVICE TO THE CARE OF TERMINAL PATIENTS
}

\author{
Daniel Pereira Francisco ${ }^{1}$, Isabelle Cristinne Pinto Costa², Cristiani Garrido de Andrade ${ }^{3}$, Kamyla Félix \\ Oliveira dos Santos ${ }^{4}$, Fabiana Medeiros de Brito ${ }^{5}$, Solange Fátima Geraldo da Costa ${ }^{6}$
}

\footnotetext{
${ }^{1}$ Undergraduate in Nursing at the Faculdade de Ciências Médicas da Paraíba (FCMPB). João Pessoa, Paraíba, Brazil. E-mail: delgba@hotmail.com

${ }^{2}$ Doctoral student in Nursing. Lecturer at the FCMPB. João Pessoa, Paraíba, Brazil. E-mail: belle_costa@hotmail.com

${ }^{3}$ M.Sc. in Nursing. Lecturer at the FCMPB. João Pessoa, Paraíba, Brazil. E-mail: cristiani_garrido@hotmail.com

${ }^{4}$ Doctoral student in Nursing at the Universidade Federal da Paraíba (UFPB). João Pessoa, Paraíba, Brazil. E-mail: kamylaoliveira@ hotmail.com

${ }^{5}$ Master's student in Nursing at the UFPB. João Pessoa, Paraíba, Brazil. E-mail: fabianabrito_@hotmail.com

${ }^{6}$ Ph.D. in Nursing. Coordinator of the Nucleus for Studies and Research in Bioethics, UFPB. João Pessoa, Paraíba, Brazil. E-mail: solangefgc@gmail.com
}

\begin{abstract}
This study aims to identify chaplains' understanding in relation to spirituality, and to analyze the chaplaincy's contribution in the care of terminal patients. It is exploratory, qualitative research undertaken with seven hospital chaplains in two public hospitals in João Pessoa in the Brazilian state of Paraíba. The data were collected through semi-structured interviews and were subjected to content analysis. The categories which emerged were: Spirituality in the view of chaplains, and Contributions of the chaplaincy in employing spirituality in the care of the terminal patient. These categories evidenced that the chaplains value the spiritual dimension in their practice, helping the patient to cope with the end-of-life process. It is hoped that this study will provide resources for further investigations, bearing in mind that studies on the chaplaincy and spirituality in the care for the terminal patient remain incipient.
\end{abstract}

DESCRIPTORS: Spirituality. Pastoral care. Terminally ill.

\section{CONTRIBUIÇÕES DO SERVIÇO DE CAPELANIA AO CUIDADO DE PACIENTES TERMINAIS}

RESUMO: Este estudo teve por objetivos identificar a compreensão dos capelães em relação à espiritualidade e analisar a contribuição da capelania no cuidado de pacientes terminais. Trata-se de pesquisa exploratória e qualitativa realizada com sete capelães hospitalares em dois hospitais públicos em João Pessoa-PB. Os dados foram coletados por meio de entrevistas semiestruturadas e submetidos à análise de conteúdo. As categorias emergidas foram: Espiritualidade na visão de capelães e Contribuições da capelania ao empregar a espiritualidade no cuidado ao paciente terminal. Tais categorias evidenciaram que os capelães valorizam a dimensão espiritual em sua prática, auxiliando o paciente a enfrentar o processo de terminalidade. Espera-se que esta pesquisa proporcione recursos para novas investigações, tendo em vista que os estudos sobre a capelania e a espiritualidade na assistência ao paciente terminal ainda são incipientes.

DESCRITORES: Espiritualidade. Assistência religiosa. Paciente terminal.

\section{CONTRIBUCIONES DEL SERVICIO DE CAPELLANÍA A LA ATENCIÓN A LOS ENFERMOS TERMINALES}

RESUMEN: Este estudio tuvo como objetivo identificar la comprensión de los capellanes con relación a la espiritualidad y analizar la contribución de la capellanía al cuidado de enfermos terminales. Esta es una investigación exploratoria y cualitativa realizada con siete capellanes hospitalarios en 2 hospitales públicos en João Pessoa, Paraíba, Brasil. Los datos fueron recogidos por medio de entrevistas semiestructuradas y sometidos a análisis de contenido. Las categorías emergidas fueron: Espiritualidad bajo la visión de capellanes y Contribuciones de la capellanía al emplear espiritualidad en el cuidado al enfermo terminal. Estas categorías mostraron que los capellanes valoran la dimensión espiritual en su práctica y ayudan al paciente a hacer frente al proceso de terminalidad. Se espera que esta investigación proporcione recursos para nuevos abordajes, teniendo en cuenta que los estudios acerca de la capellanía y la espiritualidad en la asistencia al enfermo terminal aún son incipientes.

DESCRIPTORES: Espiritualidad. Cuidado pastoral. Enfermo terminal. 


\section{INTRODUCTION}

Science is increasingly bowing before the importance of spirituality in the life of the human being. In the present day, the emphasis placed by health professionals on the aspect of spirituality is well-known. This has emerged as a theme of great importance in the care process. ${ }^{1-3}$

Interest in spirituality in the health field has never been as present as in recent years, presenting particular relevance since 2000, a year in which scientific publications on the issue grew considerably. It stands out that since the point at which beliefs and spiritual/religious practices demonstrated a strong impact on the assistance in coping with a wide variety of situations of imbalance in peoples' health, in preparing for death, and even in the health professionals' interpersonal relationships, religiosity and spirituality have come to be a milestone for the new era. However, in spite of its importance in the care, spirituality remains little addressed in scientific studies. ${ }^{1,-5}$

It stands out that spiritual experiences are often understood as religious experiences, but that - within the scientific conception - it is necessary to differentiate the two. In this regard, religion is understood as an organized system of beliefs, practices, rituals and symbols, with the aim of facilitating approximation with the transcendental, with the sacred. Spirituality, on the other hand, is a personal form of finding answers to ultimate questions relating to life, its meaning, and to the relationship with the sacred, with the transcendent; it may, or may not, lead to the development of religious rituals and to the forming of communities. ${ }^{1,6}$

As a result, spiritual care is characterized as that which affords attention and assistance to the patients' subjective and spiritual worlds, which are composed of perceptions, suppositions, feelings and beliefs about the relationship between the sacred and their illness, hospitalization, and/ or their possible death. In this context, reason must give way to sensitivity, in the sense that the needs for spiritual care may be perceived by the professionals of the interdisciplinary team and, thus, be attended respecting the specific characteristics and wishes of the patients and their family members. ${ }^{7-9}$

It is appropriate to indicate that this movement in health to contemplate the aspects of spirituality in the caring process arises from the modification of the concept of health itself, according to which the non-material dimension or the spiritual dimension is being considered. In addition to a way of being in the world, the need was established to expand scientific knowledge concerning the recognition of spiritual needs; both of the patient and of their families, and of the population in general. Thus, aspects which transcend the human being, and which achieve cosmic structures higher than the limitations imposed by the material, reinforce the mechanisms which strengthen how we interact with the other and with the world. ${ }^{1}$

In the light of this need, the access of religious people of all creeds to civil and military establishments, as well as to public and private hospitals, was assured by Brazilian Law nº. 9.982/2000, in order to offer religious and spiritual attendance to those within. Among these religious people, emphasis is placed on the chaplains, who provide religious and spiritual services to the ill in public and private hospitals, characterizing, in this way, the hospital religious service, or chaplaincy. ${ }^{4}$

It is important to emphasize that the chaplaincy's mission is to offer spiritual, emotional and social support to the ill, their caregivers and health professionals, as well as to undertake activities of spiritual care and to accompany the patients' progression, in a non-proactive way and without proselytizing. ${ }^{5,10-11}$ Such assistance must be provided regardless of religious preference, situational circumstances, sex, ethnicity, socioeconomic conditions or any other personal characteristics, thus re-establishing the interaction between spirituality and health and promoting the rapid recuperation of the patients receiving inpatient treatment, which also improves the quality of life of those in a terminal phase, who tend to mobilize and express their spirituality in a more intense form, in situations of emotional and existential crisis. ${ }^{4,12}$

It is necessary to emphasize that, in the United States and the United Kingdom, the chaplain is part of the interdisciplinary team for care to the patient, also having access to their medical records, in which they record their visits, assessments, interventions and other activities of spiritual assistance, this being a routine action within the hospitals. This fact does not yet occur in Brazil, where it may be verified that the chaplains seek the appropriate recognition of their profession and meet difficulties in accessing training courses and processes in the area. ${ }^{4,13-14}$

Even in the light of the difficult task of facing dilemmas regarding the appropriate recognition of the profession, such as difficulties in accessing training courses and processes in the area, studies have ratified the efficacy and importance of the 
chaplaincy in the health care, evidenced by the satisfaction of the population and health professionals. This service provides a model of care for solving the current gaps in the spiritual attendance of those patients who find themselves close to death, who require special treatment and care, besides reaching the family members/caregivers and the health team. Therefore, it is observed that spirituality is coupled with terminality, being an instrument of considerable relevance, given that it assists in the process of coping, of being at peace, and of having hope in the light of the occurrences. ${ }^{5,12,15-16}$

Thus, considering that the hospital chaplaincy is becoming an emerging service in Brazilian health institutions, which needs the implantation of a formal organization or institution, as it is already in place in other countries, and in the light of the scale of the chaplaincy, linked to the aspect of spirituality in the care process for the terminal patient, this study has the aim of contributing to the discussion of this issue in the health field. In the light of the above, the study had as its objectives: to identify the chaplains' understanding in relation to spirituality; and to analyze the contribution of the chaplaincy to the care of terminal patients.

\section{METHODS}

This is exploratory research with a qualitative approach. It consists of seeking meanings, significations, re-significations, psychological representations, social representations, symbolizations, symbolisms, perceptions, points of view, perspectives, experiences, life experiences, and analogies. ${ }^{17}$

The research scenario was the chaplaincy departments of two public hospitals in João Pessoa, the capital of Paraíba, Brazil. The following criteria were adopted for selection of the sample: that chaplains should accept to participate in the study freely and having been informed about it; that they should be working in the hospital selected at the time of data collection; and that they should have worked in the departments in question for a minimum period of one year. As a result, the sample was made up of seven hospital chaplains.

The data were collected in April and May 2013, through a questionnaire containing questions relevant to the objectives proposed, such as: what is your understanding regarding spirituality? How have you improved your spiritual skills for assisting the terminal patient? What are the strategies and contributions of the chaplaincy in employing spirituality in the care process for the terminal patient?

In order to viabilize data collection, the technique of semi-structured interview was used, held between Mondays and Fridays at times previously arranged with the institutions and the study participants. It is worth emphasizing that, soon after undertaking the interview, the reports were transcribed in full, a procedure which aimed to ensure the reliability of the data collection.

The empirical material arising from the interviews was codified, so as to maintain the participants' anonymity. In this way, the chaplains' accounts were indicated with the letter " $\mathrm{c}$ ", followed by the numbers $1-7$. For example: the first chaplain was codified as " $\mathrm{c1}$ "; the second, as " $\mathrm{c} 2$ ", and so on.

The material was approached qualitatively, through content analysis. This is constituted by a set of techniques which aims to obtain objective systematic procedures for describing the content and indicators of the messages, which allow the organization of these messages according to categories of communication. ${ }^{18}$ The operationalization of the content analysis has three stages: pre-analysis, the exploration of the material, and treatment of the results.

It is appropriate to indicate that the study was undertaken respecting the ethical precepts covered by Resolution $n^{\circ}$. 466/2012, of the Brazilian National Health Council, and the study was approved by the Research Ethics Committee of the Faculty of Medical Sciences of Paraíba (FCMPB), under protocol n. 267.339058/13.

\section{RESULTS AND DISCUSSION}

The data obtained in the empirical phase of the study were grouped in two categories: Spirituality in the view of chaplains; and, Contributions of the chaplaincy in employing spirituality in the care for the terminal patient.

\section{Spirituality in the view of chaplains}

Defining spirituality is shown to be highly complex and subjective, as this dimension involves meanings, propositions, and human values, such as love, compassion, empathy, honesty, responsibility, care and knowledge, among others. ${ }^{19}$

Erroneously, the terms 'spirituality' and 'religion' are frequently used as synonyms, but their meaning is not the same. Therefore, spirituality is understood as a philosophical orientation 
which produces behaviors and feelings of hope, love and faith, affording meaning to life and to the relationship with the transcendent, and which may be linked or not with a particular religion; while spirituality is not limited to aspects of dogma or doctrine. Religion, on the other hand, is belief in a divine or supernatural form, which has power over everything and is linked to specific doctrine, using practices, rituals and symbols aimed at facilitating approximation with the transcendental. ${ }^{1}$

Although they present distinct concepts, studies show that religion and spirituality are related. This relationship may be understood by the fact that, in the Middle Ages, religion had dominion over issues related to questions about heaven and earth, paradise and hell, the sacred and divine and issues concerning transcendence, generally speaking; besides this, religion has been used to facilitate access to patients' spirituality. ${ }^{20}$

In view of this, spiritual experiences are usually understood as religious experiences, which, in the scientific conception, makes it necessary to differentiate the two. Today, although the tendency is incipient, courses and means are increasingly appearing for training chaplains to understand the difference between spirituality and religion, as well as the best way to use both in assisting the terminal patient. However, there is still great difficulty in conceptualizing this dimension. ${ }^{1,4}$

The link between spirituality and religion is evidenced based in this understanding. This link can be observed in the accounts of the study participants:

spirituality, as I understand it, is when we seek to live, in truth, the word of God, the Bible, to live the Gospel, but to put it into practice, and, in truth, have a spirit of humanity, of love, of kindness for your neighbor. One very important thing is forgiveness. When we love ourselves, when we respect our neighbor, when we listen well to people, we understand better, right?! We follow the project of God through His word (c1).

I understand spirituality as something which has to do with integrality, which has to do with comfort, with support, with God, you know?! Or to have faith in that which the person has as their superior being. [...] The search for the transcendent, for the sacred; the search for meaning in life. It covers a dimension which is broader than faith in God (c3).

It is the relationship with God, with the sacred (c4).

spirituality is fundamental in life. It is... We are soul, body and spirit, you know? We only have life because we have the spirit. [...] and spirituality is primordial, because if you don't care for it, how will the body and soul be? (c5).

Emphatically, the excerpts from the accounts reveal the difficulty, the subjectivity and the insecurity in presenting the conceptual aspects regarding the spiritual dimension, although some interviewees demonstrated that they had greater dominion over the issue.

The conceptual deficiency is suggested by the use of paralinguistic elements such as pauses and conversation markers, such as, "you know", which demonstrate a certain insecurity on the part of the individual in talking about the subject.

From this perspective, it is observed that spirituality is mentioned by the chaplains as a source of comfort, as it reduces distress and produces a sensation of well-being, as well as being defined as transcendence, as it promotes self-knowledge which allows the individual to overcome the difficult period and rise above the situation imposed by the disease. It is appropriate to emphasize that one can observe, emphatically, spirituality indicated as religion - which, often, is not distinguished from spirituality which helps to deal with the disease.

It is appropriate to indicate that, in the context of health, the link between spirituality and religiosity can result in severe ethical problems, should the professionals not be alert to the limits of using the resource of faith for constructing a therapeutic link with the patient and his or her family. This fact is extremely important, given that the quality of the relationships is a crucial element for effective care, and the belief system has a direct influence on the construction of the link of care. Thus, any negative interference in the interpersonal relationships, provoking limitation or impossibility of contact, can be considered a serious assistential problem. ${ }^{1}$

It is emphasized that, in the ambit of the chaplaincy, the understanding of the spiritual dimension is strongly related to the concept of religiosity, as it is a "hospital religious service", which, according to research, consists of appropriately qualified religious work, which increasingly struggles for the recognition of the profession; increasingly, it has been sought to confer a scientific character on the training of chaplains, through seminaries, theological schools and training courses, and, thus, the certification of a profession able to offer spiritual assistance to the patient in a terminal phase. ${ }^{4,21}$

As evidenced in the accounts, although this does not yet fully function in practice and in the Brazilian context, and despite the difficulty of the 
task in confronting these dilemmas, studies ratify the emergent qualification of the chaplaincy, besides its importance in healthcare, given that this service provides a model for filling the current gaps in the spiritual care for patients who face the imminence of death. ${ }^{5}$

This growing qualification of the chaplaincy, and the search for a scientific basis for the certification of the profession and the ability to provide spiritual assistance to patients in the terminal phase may be evidenced in the following accounts:

We have courses and workshops, where we reflect; we have moments of prayer [...]. Mainly we seek God, because it is from on high that our confidence and our strength comes, our wish to do this work, which is voluntary. [...] so, primordially we seek God, through the reading of the word, through prayer, through fasting and through the training offered on the courses (c3).

as a volunteer and a member of the chaplaincy, I am always participating in the meetings [...] undertaking reading regarding the ill, reading regarding diseases, praying more and more, doing the chaplaincy course and asking for guidance from God (c4).

here in the chaplaincy, we have various workshops, [...] where we evaluate the progress of our work as chaplains; we have preparatory courses, we have the experience and the ability to, each day, improve our service of assistance. If there is a shortcoming, we go and correct it (c6).

I am improving through the reading of the word. I do the courses, I participate in meetings and workshops, besides praying and asking for guidance from the Holy Spirit (c7).

One can note, in the excerpts above, the diversity of means of training in preparation used by the chaplains in the attempt to obtain better qualification in provision of spiritual assistance to the patients who are facing the terminal phase, also emphasizing the constant mention of religious practices and reinforcing the link between religiosity and spirituality.

It is important to indicate, according to studies, that higher levels of involvement with religion/spirituality, in relation to patients with no therapeutic possibility of cure, are positively associated with indicators of physical and psychological well-being, acting as a potential factor for preventing chronic diseases, increasing survival, reducing prevalence of depression, providing more efficacious coping with the illness, low mortality, reduced time of inpatient treatment, and better immunological function..$^{22-23}$
Thus, the importance of the spiritual care provided by the chaplains is evidenced, although their qualification is shown to be increasingly necessary, such that they may promote holistic and comprehensive care for the terminal patient.

\section{Contributions of the chaplaincy in employing spirituality in the care of the terminal patient}

Transcendence becomes the essence of our life as this becomes closer to its end. Holistic and humanized care of the individuals who face the end of life must be the first assumption followed by the chaplaincy team. It is noteworthy that embracing this movement of transcendence, at this point of human existence, which is the end of life, is the primordial role of the chaplaincy, which makes the spiritual dimension of great importance in the care process. ${ }^{2,9,24}$

Studies describe the work of chaplains in the health area as the "translation" of the world of the patient for the world of hospital medicine. While the physicians tend to focus on the patients' clinical conditions, the chaplains seek to contextualize the individuals, ascertaining how their life is outside the hospital environment, what they are concerned about, what makes them happy and where they seek support for coping with problems, with various strategies being adopted for approaching the patient and for promoting spiritual care. ${ }^{21}$ Based in this premise, it was observed that some of these strategies are used by the chaplains, as the accounts below indicate:

[...] what I can do is express solidarity with him, with his problem, and seek not to resolve - because I cannot resolve - but to shape some situations. [...] and it is not just for us to talk, we have to listen too, and show the patient that he is still important in society, regardless of his condition [...] (c1).

the strategy for the promotion of this spirituality will depend on who is going to do it [...]. In the chaplaincy, we structure the support based on visits, on workshops, and on conversation circles about the Bible. We hand specialized literature to people receiving inpatient treatment, we undertake times of prayer and worship [...]. We seek a form of doing such that the people may awake, experience spirituality, understanding this strength which is powerful within them and which they sometimes do not develop or do not use, because sometimes they don't have knowledge (c3).

as chaplains, we must have discernment, to look into the patient's condition and perceive the point until which we must talk and listen; we must be sincere [...]. 
You have to know how to enter, conduct yourself, and know how to leave [...]. Here, we don't bring the patient's salvation, rather, we bring him words of comfort, of encouragement, the certainty that God is in control, that his life belongs to the Lord, that he has medical assistance here (c5).

We have the mission to get to this patient and show that he is important, but we are concerned with him [...]. We cannot be invasive in relation to this context, because, here, we are much more concerned with the spiritual aspect of the patient, reminding them of that without exposing the religious question too much, and without proselytizing (c6).

my strategy is firstly to enter the room, and approach the patient with some material, I offer - as a present - some literature, the word... I go with spiritual nourishment [...]. I have to be friendly and understand his language, because here in hospital we are dealing with various types of people [...], who do not know the word, people from other religions [...] (c7).

These accounts indicate the strategies used by the chaplains: showing solidarity; listening; undertaking visits, workshops, conversation circles, prayers and worship; the use of communication through words of encouragement and consolation; as well as the offering of presents and exploring literature regarding the issue in question.

It is important to emphasize that such accounts reveal the caution which the chaplains have regarding the patients' opinion, subjectivity and uniqueness, in adopting strategies which allow better acceptance and approximation with them, always taking into consideration, primarily, their spiritual condition; the chaplains did not mask the context through speaking of solutions, which they cannot bring, but always seek to shape the patient's situation, and are sincere with them. The accounts evidence, furthermore, the interaction between the chaplains in the health team in the care for the patient, aiming in this way to ensure holistic care, that is to say, care which is both physical and psychological.

Thus, it stands out that the chaplains present the conception that people are constituted of much more than a physical dimension, but that they also have a psychological and spiritual dimension; they considered not only their health conditions and their set of concerns and problems but also always seek to offer company and support to the patients and their caregivers, and listen to and seek to meet their deeper needs, helping them to redefine their lives. ${ }^{4,16}$

According to one study, ${ }^{21}$ some chaplains are able to translate the patients' experiences and subjectivities, enabling the health team to better understand the person who they are treating. Unlike a professional interpreter, who helps patients and doctors to communicate when they do not speak the same language, the chaplain is not a transporter of words said from one to another, but a transporter of feelings, or the emotional and spiritual needs.

One study ${ }^{5}$ describes that the chaplains are specialists in offering spiritual assistance, respecting the patients' personal beliefs, whether these are specifically religious or members of a more general category (agnostics, atheists or humanists). They can offer their time to the patients and family members in this critical period and, moreover, offer support to the health professionals. Besides this, the chaplains can help patients of different faith traditions.

The reports also denote the use of communication as a strategy for employing spirituality in the care of the terminal patient, in the sense of helping him to express feelings, providing a word of comfort, improving his self-esteem, reducing his sufferings and allowing better quality of life during difficult times.

In this regard, it is appropriate to emphasize one study which evidenced the immense valorization of communication in the context of terminality, emphasizing that it is essential for the health professional to appropriately perceive, understand and employ communication for the care of the patient who experiences the process of dying. ${ }^{25}$ Another study indicated the perception regarding the positive influence of communication in the use of religiosity/spirituality for health. ${ }^{26}$

In the light of this, the number of chaplains in Brazilian hospitals is growing, their mission being to offer spiritual, emotional and social support, attending and respecting the uniquenesses and subjectivities of the patients, their caregivers, and the health professionals. Authors ${ }^{21}$ have emphasized that, in administrative terms, it is impossible to estimate the value of a chaplain and the various benefits and consequences which the chaplaincy provides to the terminal patients and their family members and/or caregivers. There are accounts which ratify such an assertion:

there is an improvement. At least, spiritually speaking, because what is it he heard? He heard a friendly word, he saw people giving him attention, he heard the word of God, he received communion [...]. So, this makes him happy (c1).

the patient becomes happier. We see that there is an improvement, we see that some of them request another visit (c2). 
the result is tranquility; the people knew how to deal in a more balanced way with losses, with diseases, with the approximation of death, with becoming distant from their family [...]. Each time we experience a situation, and hear peoples' witness, we see how many positive results there are (c3).

the patient becomes more tranquil, more confident and, thus, this attention helps in the treatment and in his recuperation (c4).

We perceive that the physiognomy changes, that many of them had never had the opportunity to hear. [...]. We see that in that moment of pain, affliction, they seek the faith, the word [...]. They look at us, and through their eyes there is a light lit (c5).

We have reports of patients who came to hear the voice of God [...]; people who were receiving inpatient treatment in ITU, [...] considered in a terminal state, and who had a major spiritual and emotional improvement; and there has even been news of people who were completely restored (c6).

there are various. A lot of happiness, spiritual improvement, improvement in their spirits, spiritual joy (c7).

Accounts demonstrate the importance of the chaplaincy in caring for the health of terminal patients, evidenced by the clear improvement in situational states and in the spiritual conditions and through the satisfaction demonstrated by them, as the chaplains seek to undertake routine visits, gifted with sensitivity and attention, taking care and spiritual/religious support; this, in addition to ensuring that all the patients who are faced with the imminence of death, and their family members, have the opportunity to discuss their deeper needs.

In this context, one study ${ }^{27}$ indicates spirituality can have a good impact on the terminal patient's physical and emotional well-being, alleviating his pain, reducing anxiety and hopelessness, promoting within him the feeling of serenity, and facilitating the experience of the process of dying. Therefore, once such needs have been identified, the chaplain has means to intervene precisely, promoting the reduction of suffering in improving the quality of life of the patient in the terminal phase, also being able to reach his or her family members. ${ }^{27}$

In research ${ }^{10}$ undertaken to identify the patient's expectations in relation to the chaplain's visit, it was observed that nearly $70 \%$ of the interviewees reported wanting to be visited by a chaplain during their inpatient treatment. It was also ascertained that, of the patients who were visited by a hospital chaplain, $81.4 \%$ indicated this visit as of extreme importance for their quality of life. It is important to emphasize that the reason indicated most by the patients for wanting to receive a visit from a chaplain was based in the feeling of being remembered by God.

In the light of this, studies ${ }^{15-16}$ recommend the use of this model on a greater scale, both in the care of critically-ill patients and with those who have been recently-diagnosed with a chronic and/ or terminal disease.

In this perspective, the chaplain, through knowing, understanding, valuing and adopting spiritual and religious practices, can assist the patients, their family members/caregivers, and the medical team in coping with the process of becoming ill, principally when faced with the end of life.

\section{FINAL CONSIDERATIONS}

The essence of humanized care is the understanding of the multidimensionality of the human being, which is translated in the biopsychosocial and spiritual view of the patient. The chaplaincy emerges as a fundamental axis, an essential instrument, in the sense of accessing the individual's spirituality, providing support at the most difficult times of life.

Although spirituality and religion are distinct constructs, it is a fact that there is an important relationship between the two. This study corroborated this assertion through the accounts of participating chaplains. Religion emerged as a theme for access to the spiritual dimension of the individual in the terminal phase, in the sense of affording the construction of the chaplaincy's humanized, holistic and spiritual care.

In this context, it may be observed that the issue of spirituality/religion, due to its subjective characteristics, represents a major challenge for an approach with a scientific and objective character. It was evidenced that, in the context of the chaplains, spirituality has various meanings, as well as various actions and practices which characterize it.

In the light of such considerations, it is hoped that this study may instigate further reflections, relating to the valorization of the chaplaincy, such that the chaplains may appropriate spirituality as a construct of the care, in order to apply it in attention for patients in the terminal phase. Hence, considering such fruits of investigation, as well as the incipient number of professionals and studies, future studies in the area are shown to be necessary for defining the exact role of spirituality in the care for terminal patients. The advances must result from the deepening of the clinical-scientific investigations and from 
the application of spirituality in the professional practice, in particular in the management of those who are experiencing end of life.

\section{REFERENCES}

1. Penha RM, Silva MJP. Significado de espiritualidade para a enfermagem em cuidados intensivos. Texto Contexto Enferm. 2012 Abr-Jun; 21(2):260-8.

2. Peres MF, Arantes ACLQ, Lessa OS, Caous CA. A importância da integração da espiritualidade e da religiosidade no manejo da dor e dos cuidados paliativos. Rev Psiquiatr Clín. 2007; 34(sup1):82-7.

3. Willians AL. Perspectives on spirituality at the end of life: a meta-summary. Palliat Support Care. 2006 Dez; 4(4):407-17.

4. Gentil RC, Guia BPG, Sanna MC. Organização de serviços de capelania hospitalar: um estudo bibliométrico. Esc Anna Nery Rev Enferm. 2011 Jan-Mar; 15(1):162-70.

5. Pugh EJ, Smith S, Salter P. Offering spiritual support to dying patients and their families through a chaplaincy service. Nurs Times. 2010 Jul; 106(28):18-20.

6. Moreira-Almeida A, Lotufo-Neto F, Koenig HG. Religiousness and mental health: a review. Rev Bras Psiquitr. 2006 Set; 28(3):242-50.

7. Vandecreek L. Defining and advocating for spiritual care in the hospital. J Pastoral Care Counseling. 2010; 64(2):1-10.

8. Elias ACA, Giglio JS, Pimenta CAM, El-Dach LG. Programa de treinamento sobre a intervenção terapêutica "relaxamento, imagens mentais e espiritualidade" (RIME) para ressignificar a dor espiritual de pacientes terminais. Rev Psiquiatr Clín. 2007 Nov-Dez; 34(supl 1):60-72.

9. Silva DIS. Significados e práticas da espiritualidade no contexto dos cuidados paliativos em pacientes oncológicos adultos. Rev HCPA. 2011; 31(3):353-8.

10. Piderman KM, Marek DV, Jenkins SM, Johnson ME, Buryska JF, Shanafelt TD, et al. Predicting patients' expectations of hospital chaplains: a multisite survey. Mayo Clin Proc. 2010 Nov; 85(11):1002-10.

11. Winter-Pfändler U, Morgenthaler C. Patients' satisfaction with health care chaplaincy and affecting factors: an exploratory study in the German part of Switzerland. Journal of Health Care Chaplaincy. 2011; 17(3-4):146-61.

12. Weinberger-Litman SL, Muncie MA, Flannelly LT, Flannelly KJ. When do nurses refer patients to professional chaplains? Holistic Nursing Practice. 2010 Jan-Fev; 24(1):44-8.
13. Loewy RS, Loewy EH. Healthcare and the hospital chaplain. MedGenMed. 2007; 9(1):53.

14. Ott BB. Progress in ethical decision making in the care of the dying. Dimens Crit Care Nurs. 2010 Mar; 29(2):73-80.

15. Proserpio T, Piccinelli C, Clerici CA. Pastoral care in hospitals: a literature review. Tumori. 2011 Set-Out; 97(5):666-71.

16. Cooper RS. Case study of a chaplain's spiritual care for a patient with advanced metastatic breast cancer. J Health Care Chaplain. 2011; 17(1-2):19-37.

17. Turato ER. Tratado de metodologia da pesquisa clínico-qualitativa: construção teórico-epistemológica, discussão comparada nas áreas da saúde e humanas. $2^{\mathrm{a}}$ ed. Petrópolis (RJ): Vozes; 2003.

18. Bardin L. Análise de conteúdo. Lisboa (PT): Ed. 70; 2011.

19. Delgado C. A discussion of the concept os spirituality. Nurs Sci Q. 2005 Abr;18(2):157-62.

20. Vauches A. A espiritualidade na Idade Média ocidental: séculos VIII a XIII. Rio de Janeiro: Jorge Zahar; 1995.

21. Vries R, Berlinger N, Cadge W. Lost in translation: sociological observations and reflections on the practice of health care chaplaincy. Hastings Cent Rep. 2008 Nov-Dez; 38(6):23-7.

22. Rocha NS, Fleck MP. Avaliação de qualidade de vida e importância dada a espiritualidade/religiosidade/ crenças pessoais (SRPB) em adultos com e sem problemas crônicos de saúde. Rev Psiquiatr Clín. 2011; 38(1):19-23.

23. Tomasso CS, BeltrameIL, LucchettiG. Conhecimentos e atitudes de docentes e alunos em enfermagem na interface espiritualidade, religiosidade e saúde. Rev Latino-Am Enfermagem. 2011 Out; 19(5):1205-13.

24. Silva E, Sundigursky D. Concepções sobre cuidados paliativos: revisão bibliográfica. Acta Paul Enferm. 2008 ;21(3):504-8.

25. Araújo MMT, Silva MJP. Estratégias de comunicação utilizadas por profissionais de saúde na atenção à pacientes sob cuidados paliativos. Rev Esc Enferm USP. 2012 Jun; 46(3):626-32.

26. Gobatto CA, Araújo TCCF. Religiosidade e espiritualidade em oncologia: concepções de profissionais da saúde. Psicologia USP. 2013 Abr; 24(1):11-34.

27. Renz M, Schutt Mao M, Cerny T. Spirituality, psychotherapy and music in palliative câncer care: research projects in psycho-oncology at an oncology center in Switzerland. Support Care Cancer. 2005 Dez; 13(12):961-6. 